\title{
Practice and Challenges of Concerned Stakeholders' Coordination to Implement Integrated Functional Adult Literacy Program.The Case of Bale Zone of Oromia Regional State
}

\author{
Ayele Kumsa Hordofa ${ }^{1} \quad$ Abdulsemed Muhamed $^{2} \quad$ Desta Gemechu $^{3} \quad$ Fekedu Dechasa $^{3}$ \\ 1.Department of Adult Education and Community Development College of Education and Behavioral Studies \\ Madda Walabu University P O Box +251247 \\ 2.Department of English Language and Literature College of Social Science and Humanities Madda Walabu \\ University Email P O Box +251247 \\ 3.Department of Educational planning College of Education and Behavioral Studies Madda Walabu University
}

P O Box +251247

\begin{abstract}
The main objective of the study was to investigate practices and challenges of Concerned Stakeholders' Coordination to Implement Integrated Functional Adult Literacy Program. a descriptive survey method was used. Based on their closeness and geographical location, 6 Woredas were selected by multi-stage sampling technique. The sample Woredas were selected from the clusters using purposive sampling techniques. Data was collected from 230 (facilitators and Adult education Boards and technical committee). Questionnaires, interviews, document analysis, and focus group discussion were used to gather data and enrich the study. The quantitative data were analyzed using percentage and mean values while qualitative data were analyzed thematically. The finding revealed that there were: the unwillingness of concerned sectors to work together, lack of common plan and budget. Besides there is no clear and convenient organizational structures, an absence of income generation mechanisms, the absence of continuous and relevant capacity building system, lack of experience to run the program, undervaluing functional adult literacy program, lack communities participation on the strengthening the capacity of training centers. Lack of follow up the activities of concerned sectors on Adult education program implementation were some of the hindrances revealed in the study. Thus, these problems made concerned stakeholders coordination in implementing the Integrated Functional Adult Literacy Program to be incapable of meeting their purposes and the interests of disadvantaged adults and youths. It is, therefore, recommended that the Oromia Education beuros, Bale Zone and woreda Adult Education Board and Technical Committee members, facilitators and different concerned sectors have to make maximum possible efforts to mobilize all resources and stakeholders and institutions under them to reverse the current situation of concerned stakeholders coordination to implement Integrated Functional Adult Literacy Program.
\end{abstract}

DOI: $10.7176 / \mathrm{JEP} / 10-7-04$

Publication date:March $31^{\text {st }} 2019$

\section{INTRODUCTION}

Ethiopia has a long history of indigenous education which goes back to the introduction of Christianity in the $4^{\text {th }}$ century B.C (Tekeste, 1996). Particularly, the history of none formal education can be traced back to the early 20th century of Emperor Menelik and Zewditu's proclamations of "Let all learn." Next, to Minilik, Emperor Haile Selassie's Government instituted an education policy under the title Memorandum in Education Policy, which incorporated non-formal teaching methods and complementing the formal school system (Caulk, 1975: 7).

In addition, several agencies and organizations like Ethiopian Orthodox and Evangelical church, Ethiopian Women Welfare Association, etc... were participating in the adult education program.

However, during the outbreak of the revolution over $90 \%$ of the populations in Ethiopia were illiterate (Tekeste, 1990). Military Government Saves a lot of damages done, it would impossible to deny that in fact, Adult education enjoyed strong political support during the Military rule. In addition, different institutions were established to run the literacy program in the country.

After the fall of the socialist government in May 1991, the government making efforts to promote education progression through the new education and training policy since 1994 ever than before. In addition, to alleviate the adult education problems, the third and fourth educational sector programs document underscores that: lifeskill based, work-oriented and community-based adult education programs were scaled-up. The government tries to formulate strategy and ETP Integrated Functional Adult Education Program(IFAEP) to alleviate poverty. There were also opportunities for FAL program implementations in Ethiopia.

For instance: Provision of strategic guideline with the help of capacity building, the Functional Adult Literacy (FAL) Curriculum Framework, the FAL benchmarks etc... are among the known. More specifically, the government of Ethiopia play a great role so as to create an expanded Adult and Non-formal education unit and to the signing of a Memorandum of understanding between the MoE and five other ministries (Agriculture and Rural 
Development, Health, Women Affairs, Youth and Sport and Labor and Social Affairs).

There are also strategies and political will which are conducive to the provision of adult literacy, however, IFALP is not yet implemented as per to developmental and poverty reduction strategy and Its provision was engaged with problems accumulated through years. For instance, according to Oromia regional state $4^{\text {th }}$ quarter report, by 2008 literacy rate was still under $50 \%$

Without writing reading and numeracy skills, adult learners are not well equipped with skills training in areas such as agriculture, family planning, and environmental protection. Still, Adults learners are not more acquainted with technology

Even though different researches were conducted on IFALP, implementation problems are not yet solved in Oromia Regional State in general and Bale Zone in particular. Therefore, studying on the Practice and Challenges of Concerned Stakeholders' Coordination to Implement IFAL Program on Bale Woredas are very important. More specifically the result obtained from the study will expected to fill the gap between formulated IFALP policy and its actual implementation.

Accordingly, out of 20 rural Woredas which found in Bale Zone, six Woredas namely (Dinsho, Goba, Delomena, Gololcha, Rayitu, and M/Walabuu) were selected for the purpose of a study. Selecting and conducting research on these woredas may solve the challenges of concerned stakeholders' coordination to implement IFALP to the rest of Zone Woredas. Therefore, studying in this area may give a clue for restructuring and strengthening stakeholders' coordination on FALP implementation and help to close the existing research gap. Moreover, the purpose of the study was thus to investigate practices and challenges of Concerned Stakeholders' Coordination to Implement IFALP with special emphasis:

1. How do you evaluate the practice of sectors coordination towards IFAE Program implementation?

2. To what extent sectors coordination has contributed to the implementation of the FAE program?

3. What major challenges do you think are encountered concerned sectors coordination?

\section{Methods and Materials \\ Research Design}

In this study, the mixed-methods research design (using both quantitative and qualitative methods) was used. The descriptive survey was used as a quantitative research design. Descriptive survey design helps the researchers to analyze the current practices and prevailing problems by collecting data from a relatively large number of respondents (Seliger and Shohamy, 1989). Accordingly, for the quantitative aspect, closed-ended questionnaires were used by the application of a cross-sectional survey method to collect relevant data from the selected sample group. The characteristics of qualitative research are the social phenomenon being investigated from the participant's viewpoint, and experiences (Williams, 2007).

For the case of the qualitative method, semi-structured interview, open-ended, observation and Focus Group Discussion were employed to get in-depth information about the current situation of the study problem

\section{Sources of Date}

Both primary and secondary sources of data were used to collect relevant data. The Functional Adult literacy program Facilitators, Woredas Adult Education Board and Technical Committee (AEBTC) members, and Zonal (AEBTC) members were used as a source of primary data. Whereas, Bale Zone and Woreda (AEBTC) different document, work plan letters, reports of FAL centers, were used as secondary sources.

\section{Population and Sampling Procedures}

Bale Zone Woredas, Facilitators (Volunteer Teachers, Newly hired facilitators, Agriculture and Health extension workers), Zone and Woreda Adult Education Board and Technical Committee were the population of the study. The rationales for selecting Bale Zone Woredas were from the point of geographical proximity and the Zone working with Madawalabu University. First, the 20 woredas which found in Bale Zone were divided into three clusters(Goba Town CRC, Ginir Town CRC, and DelomenaWoreda CRC). From those clusters, totally 6Woredas were selected using purposive sampling techniques. Because they are currently running IFAE program and have better performance than other Woredas. Out of 250 facilitators which found in sampledWoredas 146 were selected first by stratified sampling and then by simple random sampling.

Besides, 84 (12 Zone and 72 sampled Woreda AEBTC) were all included in the study. Because they are believed to be resourceful, the most beneficiary of the program. Besides, AEBTC is more responsible to run FALP in coordination.

\section{Procedures of Data Collection}

Data were collected simultaneously by using the above four data collection instruments as indicated in the above. To administered and collected data from the field, first, six data collectors were assigned and oriented from each Sample Woredas. Furthermore, interview, FGD, Document analysis were done important by group researchers. 
Data Analysis

Analysis of data was done with the help of different techniques including both qualitative and quantitative to assess and the quantitative data were analyzed by using descriptive statistics or simple statistical tools such as percentage and mean values. The results of the analysis were summarized and presented by tables. Besides, qualitative data obtained through Interview, open-ended questions, FGD, and document analysis were analyzed and presented through narration. Various archives were also reviewed, analyzed and applied to substantiate primary data.

\section{Ethical consideration}

The research was conducted in consideration of all ethical issues of research. The participants were briefed about the purpose of the study and ask for their informed consent to be involved in the study. The interviews were conducted separately and in private except focus group discussion. The researcher developed a relationship with the participants to encourage optimum responses in a naturalistic environment. The participants were assured of the confidentiality of all data collected. Hence, the name of the school and the participants were remaining unidentified and all data was confidential to the researcher. In addition, all participants were advised of their rights to withdraw or refuse to participate in the research at any stage.

\section{Result \& Discussion}

Out of the total 218 questionnaires distributed to collect data for the study, $206(99.1 \%)$ were returned and used in the data analysis. The information obtained from these questionnaires were presented and analyzed as follows. In addition, Dabal, Hundessa (2011) on his summary of findings indicated that Females participation was very low in the process of FALP implementation

\section{The practice of sectors coordination towards IFAE Program implementation.}

The majorities $86(59.7 \%)$ of facilitators and only $18(29.0 \%)$ of WAEBTC have on the job training in relation to current position, whereas only $58(40.0 \%)$ of facilitators and the majorities $44(71.0 \%)$ of WAEBTC respondents haven't got on the job training. On the same table, the majorities $84(97.7 \%)$ of facilitators and $18(100 \%)$ of WAEBTC members who took training replied that training is not enough. Besides, The majorities $103(71.5 \%)$ of facilitators and $47(75.8 \%)$ of Woreda AEBTC members replied that there is a shortage of IFAE implementing guideline in the centers.

\section{Table 1 on the work raining of Facilitators and AEBTC members}

$$
\text { Activities Responses }
$$

1

Do you have on the job yes training in relation to the No current position?

2 if yes", how do you evaluate the training?

3 Do you have the IFAL Yes program implementation No Guideline?

Not Known

Enough not Enough

Not known

\begin{tabular}{lrr}
\multicolumn{3}{l}{ Facilitators } \\
$\mathrm{f}$ & \multicolumn{3}{c}{$\%$} \\
& 86 & 59.7 \\
& 58 & 40.3
\end{tabular}

$2 \quad 2.3$

\section{Respondent Groups} WAEBTC$$
\text { f } \%
$$$$
18 \quad 29.0
$$

44

71.0

$\mathrm{f}$
f 104

$84 \quad 97.7$

$\begin{array}{ll}0 & \\ & 18\end{array}$

$$
0.0
$$

100

2
102

98.1

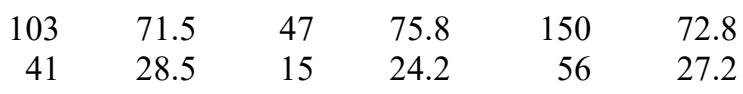

With regards to table 2 of items 3, 4, 7 and 8, the majority of respondents (facilitators and WAEBTC members) confirmed that sectors are not in the position to evaluate syllabus and curriculum of IFAE program. Besides in most Woreda of Bale Zone, sectors representative and education office from Zone to the grass root level, have no common criteria to evaluate integrated functional adult education program. NGO and private sectors are not encouraged to invest their knowledge and economy on IFAE centers. Furthermore, adult education experts are not hired both in Woreda and adult education centers. The combined mean score of all items was 2.51. This revealed their degree of agreement on item mentioned above respectively.

Similarly, as it can be seen in Table 2 the majorities $132(91.7 \%)$ of facilitators were disagreed to the idea of there are common discussion schedules on functional adult education program implementation. However, $34(54.8 \%)$ of WAEBTC members agreed that they have common discussion schedules. Even though there is a contradiction between the two group respondents, the result obtained from interview and document analysis revealed that in Bale ZonWoredas both sector facilitators and Woreda AEBTC members have no clearly identified and known common schedules on IFAE program implementation

With regards to workplace training the majority $121(84.0 \%)$ of facilitators and $56(90.3 \%)$ of WAEBTC members confirmed that workplace training was given only for newly hired education sector facilitators. The average mean score of the two group respondents was found to be 4.78 . This is strongly agreed. 
Table 2 practice of implementing Functional Adult education program No

$$
\text { Activities (Items) }
$$

Responses

1 Teaching material standard and its SA distribution are well known

2 Teaching materials, published and printed only by MoE,

3 Sectors are in a position to evaluate syllabus and curriculum of IFAEP.

4 There are common evaluating criteria of IFAE program.

5 There are common discussion schedules on FAE program implementation sectors participate in teaching-learning process based on common agreement

$7 \quad$ NGO's and private sectors are encouraged to invest in FAE centers.

8 Adult educations experts hired according to government structure.

Workplace training was given only for
newly hired education facilitators.

\section{A \\ DA \\ Mean}

SA

A

Mean

A

UN

DA

Mean

DA

SD

Mean

A

DA

SD

Mean

A

DA

SD

Mean

DA

SD

UD

Mean

A

DA

SD

UD

Mean

SA

A

UD

Mean

\begin{tabular}{|c|c|}
\hline \multicolumn{2}{|c|}{ Facilitators } \\
\hline$f$ & $\%$ \\
\hline 6 & 4.2 \\
\hline 22 & 15.3 \\
\hline 116 & 80.6 \\
\hline 2.28 & \\
\hline 123 & 85.4 \\
\hline 21 & 14.6 \\
\hline 4.85 & \\
\hline 28 & 19.4 \\
\hline 5 & 3.5 \\
\hline 111 & 77.1 \\
\hline 2.42 & \\
\hline 88 & 61.1 \\
\hline 56 & 38.9 \\
\hline 1.61 & \\
\hline & 0.0 \\
\hline 132 & 91.7 \\
\hline 12 & 8.3 \\
\hline 1.92 & \\
\hline 7 & 4.9 \\
\hline 131 & 91.0 \\
\hline 6 & 4.2 \\
\hline 2.10 & 1.5 \\
\hline 123 & 85.4 \\
\hline 11 & 7.6 \\
\hline 10 & 6.9 \\
\hline 2.00 & \\
\hline 12 & 8.3 \\
\hline 116 & 80.6 \\
\hline 16 & 11.1 \\
\hline & 0.0 \\
\hline 2.10 & \\
\hline 121 & 84.0 \\
\hline 13 & 9.0 \\
\hline 10 & 6.9 \\
\hline 4.77 & \\
\hline
\end{tabular}

Respondent Groups

WAEBTC Total f $\%$ f $\%$

$\begin{array}{llll}8 & 12.9 & 14 & 6.8\end{array}$

$\begin{array}{llll}20 & 32.3 & 42 & 20.4\end{array}$

$\begin{array}{llll}34 & 54.8 & 150 & 72.8\end{array}$

$2.71 \quad 2.49$

$\begin{array}{llll}58 & 93.5 & 181 & 87.9\end{array}$

$\begin{array}{rrrr}4 & 6.5 & 25 & 12.1\end{array}$

$\begin{array}{rrrr}3 & 4.8 & 31 & 15.0\end{array}$

$\begin{array}{rrr}3 & 5.4\end{array}$

$\begin{array}{llll}59 & 95.2 & 170 & 82.5\end{array}$

$2.10 \quad 2.26$

$\begin{array}{llll}56 & 90.3 & 144 & 69.9\end{array}$

$\begin{array}{llll}6 & 9.7 & 62 & 30.1\end{array}$

$\begin{array}{rrrr}\mathbf{1 . 9} & & \mathbf{1 . 7 6} & \\ 34 & 54.8 & 34 & 16.5\end{array}$

$\begin{array}{llrr}28 & 45.2 & 160 & 77.7\end{array}$

$\begin{array}{rrrr}\mathbf{3 . 1} & & \mathbf{2 . 5 1} & \\ \mathbf{3 8} & 61.3 & 45 & 21.8 \\ 28 & 45.2 & 159 & 77.2\end{array}$

$\begin{array}{rrrr}6 & 9.7 & 12 & 5.8\end{array}$

$\begin{array}{ll}3.45 & \mathbf{2 . 7 8}\end{array}$

$\begin{array}{llll}54 & 87.1 & 177 & 85.9\end{array}$

$\begin{array}{llll}8 & 12.9 & 19 & 9.2\end{array}$

$\begin{array}{rrr}0.0 & 10 & 4.9\end{array}$

$\begin{array}{rrrr}1.87 & & 1.94 & \\ 32 & 51.6 & 44 & 21.4\end{array}$

$\begin{array}{llll}16 & 25.8 & 132 & 64.1\end{array}$

$\begin{array}{llll}12 & 19.4 & 28 & 13.6\end{array}$

$\begin{array}{rrrr}4 & 6.5 & 4 & 1.9\end{array}$

$\begin{array}{rrrr}\mathbf{2 . 7 7} & & \mathbf{2 . 4 4} & \\ 56 & 90.3 & 177 & 85.9\end{array}$

$\begin{array}{lrrr}4 & 6.5 & 17 & 8.3\end{array}$

$\begin{array}{rrrr}2 & 3.2 & 12 & 5.8\end{array}$

$\begin{array}{ll}4.87 & 3.2 \\ 2.82\end{array}$

Note: Mean scores obtained from the data were interpreted as: $0.05-1.49=S D, 1.50-2.49=D A, 2.50-3.49=N T$, 3.50-4.49= $A$, and above $4.50=S A$

\section{Attitude of concerned sectors toward implementing FAE program}

Data presented in Table 2 below further shows the attitude of concerned sectors toward implementing FAE program. To this regard items: 1, 4, 6 and 7 respectively present the degree to which concerned sectors believe that IFAE program is only the work of education sectors, whether or not adult education members give due attention for running the program, whether or not adult Education program is difficult tasks to implement, whether or not training given for adult in their workplace, are considered as adult education and whether or not training is given for adult in hospital and their home are considered as parts of adult education. Accordingly, the average mean score of respondents (facilitators and WAEBTC members) for the mentioned items were respectively 3.85, 3.99, 3.65, 3.69 and 3.82. This revealed respondents (facilitators and WAEBTC members) degree of agreement.

Furthermore, the result obtained from FGD and interview confirmed that most sectors, Zone and Woreda cabinet, perceived adult Education program as difficult and additional tasks. Most interviewees training is given for adult in their workplace, in the hospital and their home is not considered parts of adult education. However, in the developed North, workplace learning is formal, non-formal and informal for New Zealand (Madhu S. 2015)

Data presented in the same table 3 further shows that, the majorities of respondents (facilitators and WAEBTC members) have no clear ideas such as: Undermining the program as no value in reduction of poverty, concerned sectors prefer to help adult learners than teach them and adult education structure is only known by education 
sectors of items: 3,5 and 8 respectively. The average mean scores were 3.27, 3.46 and 3.04 is neutral. However, the result obtained from perceived adult education as no value in the reduction of poverty. Most NGOs and private sectors are not in a position to teach adult learners. Most of the time, they focus on helping with money and material supply. Concerning adult education structure, the interviewees confirm that, adult education structure is only known by education sectors. Health and agriculture sectors still didn't have IFAE structure.

With regards to item 9 of the same table, the majorities of respondents (Facilitators and WAEBTC members) strongly agreed that, in bale Zone Woredas and their respective IFAE centers, most concerned sectors expect the program as additional work. The average mean value was 4.77 which is strongly agree

Table 3 Respondents opinions on coordinate implementation of Adult education

No Activities (Items)

1 Concerned sectors believed that IFAE Program as the work of education sectors only

2 AEBTC members are not given due attention for running the program

Undermining the program as no value in reduction of poverty.

4 Adult Education program is a difficult tasks to implement in coordination.

5 Concerned sectors prefer to help adult learners than teach them

6 Training given for adult in their workplace, are not considered as adult education.

7 Training is given for adult in a hospital and their home is not considered as parts of adult education.

8 Adult education structure is only known by education sectors,

Most concerned sectors expected IFAE as an
additional work
additional work

\section{Responses}

SA

A

DA

Mean

SA

A

DA

Mean

A

UN

DA

Mean

A

DA

Mean

A

DA

SD

Mean

A

UD

DA

Mean

A

UN

DA

Mean

A

DA

SD

UD

Mean

SA

A

UD

Mean
Respondent Groups

Facilitators WAEBTC Total

$\begin{array}{lclccc}\mathrm{f} & \% & \mathrm{f} & \% & \mathrm{f} & \% \\ 91 & 63.2 & 34 & 54.8 & 125 & 60.7\end{array}$

$\begin{array}{rrrrrr}5 & 3.5 & 10 & 16.1 & 15 & 7.3\end{array}$

$\begin{array}{llllll}48 & 33.3 & 18 & 29.0 & 66 & 32.0\end{array}$

$\begin{array}{lll}3.93 & 3.96 & 3.95\end{array}$

$\begin{array}{llllll}123 & 85.4 & 27 & 43.5 & 150 & 72.8\end{array}$

$\begin{array}{llllll}21 & 14.6 & 7 & 11.3 & 28 & 13.6\end{array}$

$\begin{array}{rrrrrr} & 0.0 & 28 & 45.2 & 28 & 13.6\end{array}$

$\begin{array}{rrrrrr}111 & 77.1 & 27 & 43.5 & 138 & 67.0\end{array}$

$\begin{array}{llllll}6 & 4.2 & 5 & 8.1 & 11 & 5.3\end{array}$

$\begin{array}{rrrrrr}27 & 18.8 & 30 & 48.4 & 57 & 27.7\end{array}$

$\begin{array}{lll}3.58 & 2.95 & 3.27\end{array}$

$\begin{array}{llllll}133 & 92.4 & 45 & 72.6 & 178 & 86.4\end{array}$

$\begin{array}{llllll}11 & 7.6 & 17 & 27.4 & 28 & 13.6\end{array}$

$\begin{array}{lll}3.85 & 3.45 & 3.65\end{array}$

$\begin{array}{rrrrrr}129 & 89.6 & 39 & 62.9 & 168 & 81.6\end{array}$

$\begin{array}{llllll}11 & 7.6 & 18 & 29.0 & 29 & 14.1\end{array}$

$\begin{array}{rrrrrr}4 & 2.8 & 5 & 8.1 & 9 & 4.4\end{array}$

$\begin{array}{lll}3.76 & 3.17 & 3.46\end{array}$

$\begin{array}{llllll}117 & 81.3 & 48 & 77.4 & 165 & 80.1\end{array}$

$\begin{array}{rrrrrr}6 & 4.2 & 12 & 19.4 & 18 & 8.7\end{array}$

$\begin{array}{rrrrrr}19 & 13.2 & 2 & 3.2 & 21 & 10.2\end{array}$

$\begin{array}{lll}3.64 & 3.74 & 3.69\end{array}$

$\begin{array}{rrrrrr}\mathbf{3 . 6 4} & & \mathbf{3 . 7 4} & & \mathbf{3 . 6 9} & \\ 134 & 93.1 & 51 & 82.3 & 185 & 89.8\end{array}$

$\begin{array}{llllll}3 & 2.1 & 7 & 11.3 & 10 & 4.9\end{array}$

$\begin{array}{rrrrrr}7 & 4.9 & 4 & 6.5 & 11 & 5.3\end{array}$

$\begin{array}{lll}3.88 & 3.76 & 3.82\end{array}$

$\begin{array}{lrrrrr}90 & 62.5 & 30 & 48.4 & 120 & 58.3\end{array}$

$\begin{array}{llllll}40 & 27.8 & 25 & 40.3 & 65 & 31.6\end{array}$

$\begin{array}{llllll}14 & 9.7 & 5 & 8.1 & 19 & 9.2\end{array}$

$\begin{array}{rrrrrr} & 0.0 & 2 & 3.2 & 2 & 1.0\end{array}$

$\begin{array}{llllll}126 & 87.5 & 51 & 82.3 & 177 & 85.9\end{array}$

$\begin{array}{llllll}14 & 9.7 & 3 & 4.8 & 17 & 8.3\end{array}$

$\begin{array}{rrrrrr}4 & 2.8 & 8 & 12.9 & 12 & 5.8\end{array}$

$\begin{array}{lll}4.85 & 4.69 & 4.77\end{array}$

Note: Mean scores obtained from the data were interpreted as: $0.05-1.49=S D, 1.50-2.49=D A, 2.50-3.49=N T$, 3.50-4.49 $=A$, and above $4.50=S A$

\section{Commitments of concerned sectors toward implementing FAE program}

Data presented in Table 4 item 1 below further shows the extent to which sectors are committed to implementing the IFAL program as per government guideline. Accordingly, the majorities $111(77.1 \%)$ of facilitators were replied that concerned sectors are not committed to implementing the IFAL program as per government guideline. However, the majorities 44(71.0\%) of Woreda Adult education Board and Technical Committee members were replied that sectors are committed to implementing the IFAL program as per government guideline. The two group respondent responses were contradicted.

According to Focus Group Discussion members and interviewees, in Bale zone Woredas and their respective 
IFAE center, concerned sectors, administrative bodies, Cabinet, teachers and center supervisors are not committed to implementing IFAL program as per government guideline. This revealed that with the exception of education sectors are not commuted to implement IFAL program as per government guide line.

As it has presented on the below Table 4 the average mean values of respondents (facilitators and WAEBTC members) of items such as: "political leaders committed to implementing IFAE program, most AEBTC commitment to assess the need before training, and Concerned sectors

are commuted to know concept of FAL program" are respectively $2.49,2.40$ and 2.24. This shows a low commitment of political leaders, WAEBTC members and concerned sectors to implement, to assess the need before training and to know concepts of IFAE program respectively. This idea is supported by Zone interviewees that, most political leaders from the grass root level to Region, lack moral to implement IFAE program as to government policy. Besides the FGD members confirmed that, no trends of assessing the need of facilitators, adult learners before conducting training.

As shown in table 4 item 3 below, the majorities $123(85.4 \%)$ of facilitators rate commitment of AEBTCs to improve the acceptance of adult education in training centers as low. However, the majorities $32(51.6 \%)$ of WAEBTC members replied that WAEBTC is highly commuted to improve the acceptance of adult education in training centers. There are two contradict ideas. To this end, the Focus Group Discussion result revealed that in all Woredas training centers are controlled most of the time by education sectors facilitators. No one participates and commuted to improve the acceptance of adult education in training centers.

Table 4 the degree to which Sectors committed on coordinate implementation

No Activities (Items)

1 The extent to which Sectors are committed to implementing the IFAL program as per government guideline.

2 political leaders committed to implement IFAE program

3 A commitment of AEBTCs to improve the acceptance of adult education in training centers

4 Concerned sectors are commuted to know the concept of FAL program

$\mathrm{H}$

MD

L

Mean

$\mathrm{H}$

MD

$\mathrm{L}$

Mean

$\mathrm{H}$

$\mathrm{MD}$

L

Mean

$\mathrm{H}$

MD

L

Mean

5 Most AEBTC commitment to assess the need before training.
Respondent Groups

\begin{tabular}{rrrlrr}
\multicolumn{2}{r}{ Facilitators } & \multicolumn{2}{c}{ WAEBTC } & \multicolumn{2}{c}{ Total } \\
$\mathrm{f}$ & \multicolumn{1}{c}{ \% } & $\mathrm{f}$ & \multicolumn{1}{l}{$\%$} & \multicolumn{1}{c}{$\mathrm{f}$} & $\%$ \\
23 & 16.0 & 44 & 71.0 & 67 & 32.5 \\
10 & 6.9 & 11 & 17.7 & 21 & 10.2 \\
111 & 77.1 & 7 & 11.3 & 118 & 57.3 \\
$\mathbf{2 . 3 9}$ & & $\mathbf{3 . 6 0}$ & & $\mathbf{2 . 9 9}$ & \\
15 & 10.4 & 20 & 32.3 & 35 & 17.0 \\
10 & 6.9 & 4 & 6.5 & 14 & 6.8 \\
119 & 82.6 & 38 & 61.3 & 157 & 76.2 \\
$\mathbf{2 . 2 8}$ & & $\mathbf{2 . 7 1}$ & & $\mathbf{2 . 4 9}$ & \\
10 & 6.9 & 32 & 51.6 & 42 & 20.4 \\
11 & 7.6 & 20 & 32.3 & 31 & 15.0 \\
123 & 85.4 & 10 & 16.1 & 133 & 64.6 \\
& & $\mathbf{3 . 3 5}$ & & $\mathbf{2 . 8 4}$ & \\
17 & 11.8 & 6 & 9.7 & 23 & 11.2 \\
27 & 18.8 & 12 & 19.4 & 39 & 18.9 \\
100 & 69.4 & 44 & 71.0 & 144 & 69.9 \\
$\mathbf{2 . 4 2}$ & & $\mathbf{2 . 3 9}$ & & $\mathbf{2 . 4 0}$ & \\
$\mathbf{1 0}$ & 6.9 & 2 & 3.2 & 12 & 5.8 \\
$\mathbf{1 1}$ & 7.6 & 12 & 19.4 & 23 & 11.2 \\
$\mathbf{1 2 3}$ & 85.4 & 48 & 77.4 & 171 & 83.0 \\
$\mathbf{2 . 2 2}$ & & $\mathbf{2 . 2 6}$ & & $\mathbf{2 . 2 4}$ &
\end{tabular}

Note: Mean scores obtained from the data were interpreted as: $0.05-1.49=V L, 1.50-2.49=L, 2.50-3.49=M D$, 3.50-4.49= $\mathrm{H}$, and above $4.50=\mathrm{VH}$

Contribution of sectors coordination to the implementation of FAE program

As Table 5 depicts, the majorities of respondents (facilitators and WAEBTC members) replied that their documentation practice (Recording, Reporting etc) in the FAL centers were at medium level. The average mean value was 2.70. Document analysis result obtained from Rayitu Woreda confirmed that all IFAE centers have their own learner roster, adult learner attendance, and monthly report file. Education sectors also compiled all documents as much as they can. But the way it handled and reported are not as much interested

Similarly, the ratings of facilitators and WAEBTC respondents for the items:"Boards and technical committee self-initiation to help facilitators, Extent to which facilitators/ trainees are encouraged, Extent of clearly identified authorities, duties and responsibilities of tasks and Effectiveness, efficiency and flexible administrative structure" were all rated on average 2.38, 2.29, 2.16 and 2.40 respectively. The average mean scours show respondents' low contributions on self-initiation, trainees' encouragement. Besides, there is no clearly identified authority, duties and responsibilities of tasks and IFAE centers lack flexible administrative structure. 
Table 5 Degree to which sectors contributed to the implementation of the FAE program

No

\section{Activities (Items)}

1 Documentation

practice

( Recording, Reporting etc) in the FAL centers

2 Boards and technical committee self-initiation to help facilitators

3 The extent to which facilitators/ trainees are encouraged

4 The extent of clearly identified authorities, duties, and responsibilities of tasks

5 Effectiveness, efficiency and $\mathrm{H}$ flexible administrative structure $\quad \mathrm{M}$ $\mathrm{M}$
$\mathrm{VL}$

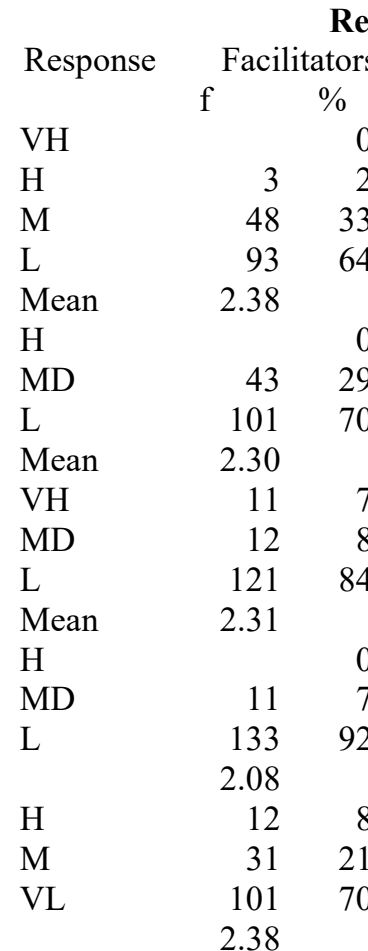

Respondent Groups

WAEBTC

f $\%$

0.0

2.1

3

11

4.8
17.7

f

Total

33.3

64.6

12

19.4

74.2

46
3.02

$\begin{array}{lrr}0.0 & 4 & 6.5\end{array}$

$6.5 \quad 4$

33.9

59.7

37

2.47

$7.6 \quad 2$

$8.3 \quad 11$

84.0

49

49
2.27

$\begin{array}{lr}0.0 & 1\end{array}$

$7.6 \quad 13$

92.4

48
2.24

$\begin{array}{rr}8.3 & 3.24 \\ 21.5 & 20\end{array}$

$70.1 \quad 39$

2.42

Note: Mean scores obtained from the data were interpreted as: $0.05-1.49=V L, 1.50-2.49=L, 2.50-3.49=M D$, 3.50-4.49 $=\mathrm{H}$, and above $4.50=\mathrm{VH}$

\section{Challenges encountered concerned sectors coordination}

As can be seen in the Table 6, of items: 1, 2, 4 and 10, lack of appropriate and attractive FAE center to bring all concerned sectors, lack of motivation and incentive for members of board and technical committee, lack of common plan to govern all concerned sectors coordinately were respectively the main problems encountered concerned sectors coordination to implement IFAE program as per government policy. The average mean scours of respondents (facilitators and WAEBTC members) were respectively 4.7, 4.88, 4.87 and 4.87 which indicated the challenges encountered concerned sectors coordination for the above-listed items were all very high. During the focus group discussion and interview most of the participants complain that there is lack of motivation and incentive for members of the board and technical committee to come together and discuss on the agenda of adult education in general and IFAE center in particular. From grass root level to Woreda and Zone, All center plans are prepared by education sectors. Other sectors involvements are not seen.

On the same table of items: 3,5, 7, 8 and 9"Lack of guideline to govern all concerned sectors to work coordinately, lack of new graduated IFAE experts to run the program, ABC members are not qualified with the fields of adult education, concerned sectors lack different between formal and adult education and contents of adult education are not equally accepted among concerned sectors" were also replied by majorities of respondents(facilitators and WAEBTC members) challenges encountered concerned sectors coordination to implement Integrated Functional Adult Education as Government policy and MoE Memorandum of Understanding. Bale Zone Interviewees and Focus Group discussion Participants confirmed the above-mentioned ideas.

For instance, as mentioned by interviewees, most concerned sectors still have a problem with the difference between formal and nonformal education. They categorize adult education under formal education.

FGD result also revealed that in all Bale Zone Woredas and their respective IFAE training centers newly graduated experts are not hired. This is because of a lack of budget. Woreda is not ready to hire a newly graduated student.

Regarding the material distribution of item 6 below, the majorities 78(54.2\%) of facilitators strongly agree that there is an unequal distribution of reading writing and numeracy materials in IFAE training centers. However, majorities $47(75.8 \%$ ) of WAEBTC members disagreed to the idea that unequal distribution of reading writing and numeracy materials. Even though there are two contradicting ideas, the result obtained from training center observation and woreda document analysis confirmed the idea of facilitator respondents. The observation result revealed that, most reading writing and numeracy materials found in Woreda stores. Not equally distributed to the training center. 
Table 6 factors affection concerned sectors coordination to implement IFAE program

No

1 Lack of appropriate and attractive SA FAE center to bring all concerned A sectors.

2 Lack of motivation and incentive for members of the board and technical committee.

3 Lack of guideline to govern all concerned sectors to work coordinately.

4 Lack of a common plan to govern all concerned sectors coordinately.

5 Lack of new graduated IFAE experts to run the program.

6 Unequal distribution of reading writing and numeracy materials.

AEBTC members are not qualified with the fields of adult education.

Concerned sectors lack different between formal and adult education.

9 Contents of adult education are not equally accepted among concerned sectors.

10 Lack of Budget to run the program

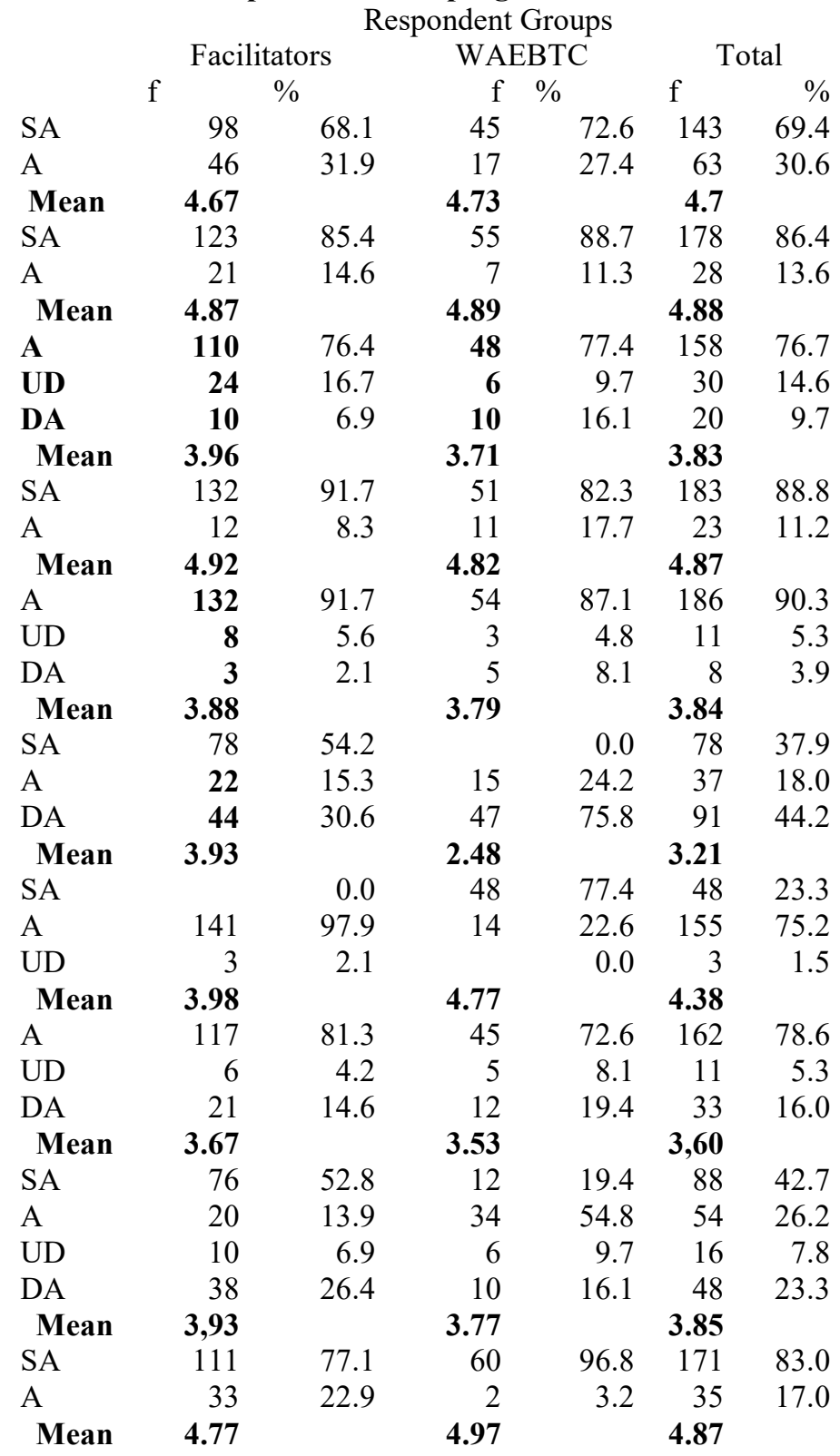

Note: Mean scores obtained from the data were interpreted as: $0.05-1.49=V L, 1.50-2.49=L, 2.50-3.49=M D$, 3.50-4.49 $=\mathrm{H}$, and above $4.50=\mathrm{VH}$

\section{Conclusions}

The main objective of the study was to investigate practices and challenges of Concerned Stakeholders' Coordination to Implement Integrated Functional Adult Literacy Program in Bale Zone selected Woredas. Accordingly, Out of the total 218 questionnaires distributed to collect data for the study, 206 (99.1\%) were returned and used in the data analysis. The information obtained from these questionnaires were presented and analyzed as follows.

The practice of sectors coordination towards IFAE Program implementation.

Most facilitators and WAEBTC haven't got on the job training in relation to their current position. Woreda AEBTC members replied that there is a shortage of IFAE implementing guideline in the centers. Besides, the finding revealed that sectors are not in a position to evaluate syllabus and curriculum of IFAE program.

In most Woreda of Bale Zone, sectors representative and education office from Zone to the grass root level, have no common criteria to evaluate integrated functional adult education program. The finding from this study confirms that of Sisay A. \& Yilfashewa S. ( 2017) finding on Integrated Functional Adult Literacy: Existing Practices and Challenges in Eastern Ethiopia 
In most Bale Zone, Woredas, NGO and private sectors are not encouraged to invest their knowledge and economy on IFAE centers. The result also revealed that adult education experts are not hired both in Woreda and adult education centers. In this study, it was found out that both sector facilitators and Woreda AEBTC members have no clearly identified and known common schedules on IFAE program implementation. The result obtained by Abebe Anjulo Teklu Gebretsadik Mekonne Debra (2017) confirmed the above ideas

\section{An attitude of concerned sectors toward implementing FAE program}

The result obtained from FGD and interview confirmed that most sectors, Zone and Woreda cabinet, perceived adult Education program as difficult and additional tasks. Most interviewees responses revealed that training is given for adult in their workplace, in the hospital and their home are not considered as parts of adult education. However, in the developed North, workplace learning is formal, non-formal and informal for New Zealand (Madhu S. 2015). NGOs and private sectors are not in a position to teach adult learners. They focus on helping with money and material supply. Besides, Adult education structure is only known by education sectors. Health and agriculture sectors still didn't have their own IFAE structure.

\section{Commitments of concerned sectors toward implementing FAE program}

In Bale zone, Woredas and their respective IFAE center, concerned sectors, administrative bodies, Cabinet, teachers and center supervisors are not committed to implementing the IFAL program as per government guideline. With the exception of education, sectors are not commuted to implement IFAL program as per government guide line. The result also revealed that most political leaders from the grass root level to Region, lack moral to implement IFAE program as to government policy. the result confirmed Samuel Asnake Wollie (2012) summery on how to help adults learn the alphabet, reading and writing skills seem a clear gap Jimma, Ethiopia,

The results of the current study unveiled that no trends of assessing the need for facilitators, adult learners before conducting training. With regards to management, in all Woredas, training centers are controlled by education sectors facilitators. No one participates and commuted to improve the acceptance of adult education in training centers. The finding from this study confirms the result obtained by Oyebamiji Morufu A.(2015) on Problems of Adult Education in Nigeria

\section{The contribution of sectors coordination to the implementation of the FAE program}

Even though all IFAE centers have their own learner roster, adult learner attendance and monthly report file, the finding revealed that all documents are compiled and reported by education sectors. Document analysis result revealed that the way facilitators, technical committee and other concerned stakeholders' handle result documents and report are not clear. no, clearly identified authority, duties and responsibilities of tasks and IFAE centers lack flexible administrative structure. The result obtained by Ms. M. Mashinkila \& Mr. M. Assefaw. (2001) on Appraisal Report Skills Development and Income Generation Project Republic of Malawi supported the above ideas.

\section{Challenges encountered concerned sectors coordination}

There is a lack of motivation and incentive for members of the board and technical committee to come together and discuss on the agenda of adult education in general and IFAE center in particular. As replied by majorities of respondents (facilitators and WAEBTC members) challenges encountered concerned sectors coordination to implement Integrated Functional Adult Education as Government policy and MoE Memorandum of Understanding.

Similarly, local research conducted by Mohammed (2013) concluded that, Lack of guideline to govern all concerned sectors to work coordinately, lack of new graduated IFAE experts, lack of qualified AEBTC members with the fields of adult education, mixing the concept of formal and adult education, problem of treating adult education equally to formal education. Most concerned sectors categorize adult education under formal education. These results are similar to that of problems identified from different literacy programs (David, 2001; Hildebrand, 1999; Nibuagbaw, 2001)

In all Bale Zone Woredas and their respective IFAE training centers newly graduated experts are not hired. This is because of a lack of budget. Woreda is not ready to hire a newly graduated student. The result obtained from training center observation and woreda document analysis confirmed the idea of facilitator respondents. The observation result revealed that, most reading writing and numeracy materials found in Woreda stores. Not equally distributed to the training center.

Mulugeta Menkir (2002) On His research major finding and discussion, confirmed the above idea that, although, the Government has adopted the concept of functional literacy, the attainment of literacy skills has been very limited. For instance, lack of linkage between functional literacy courses and the Government socio-economic and community development activities; lack of reliable and permanent funding for the program and supply of instructional materials; inadequate follow-up and monitoring of the functional literacy activities by the various providers. Besides, inadequate integration of literacy delivery services and follow-up as well as poor management 
due to the insufficient capacity facilitators and AEBTC. Besides, the result also confirmed the idea of Abeje Gudeta, (2017) that the variety of institutional and financial arrangements are also challenges encountered in concerned sectors coordination.

\section{Conclusions}

1. From the finding it is concluded that, Most facilitators and WAEBTC haven't got on the job training in relation to their current position; there is shortage of IFAE implementing guide line in the centers; sectors are not in position to evaluate syllabus and curriculum of IFAE program; sectors have no common criteria to evaluate integrated functional adult education program; NGO and private sectors are not encouraged to invest their knowledge and economy on IFAE centers; adult education experts are not hired both in Woreda and adult education centers and both sector facilitators and Woreda AEBTC members have no clearly identified and known common schedules on IFAE program implementation. Therefore, it is recommended that, structure of adult education should be revised and re arranged so as to minimize the problem.

2. most sectors, Zone and Woreda cabinet, perceived adult Education program as difficult and additional tasks. training given for adult in their workplace, in hospital and their home are not considered as parts of adult education; NGOs and private sectors are not in position to teach adult learners. They focus on helping with money and material supply. Besides, Adult education structure is only known by education sectors. Health and agriculture sectors still didn't have their own IFAE structure.

3. Except education sectors, other sectors are not commuted to implement IFAL program as per government guide line; most political leaders from the grass root level to Region, lack moral to implement IFAE program as to government policy.

4. no trends of assessing the need of facilitators,

5. the way facilitators, technical committee and other concerned stakeholders' handle result documents and report are not clear. no clearly identified authority, duties and responsibilities of tasks and IFAE centers lack flexible administrative structure.

6. lack of motivation and incentive for members of board and technical committee to come together and discuss on the agenda of adult education

7. Lack of guide line to govern all concerned sectors to work coordinately, lack of new graduated IFAE experts, lack of qualified AEBTC members with the fields of adult education, mixing the concept of formal and adult education, problem of treating adult education equally to formal education.

8. lack of linkage between functional literacy courses and the Government socio-economic and community development activities; inadequate follow-up and monitoring, poor management due to the insufficient capacity facilitators, variety of institutional and financial arrangements are also challenges encountered concerned sectors coordination.

\section{Recommendation}

Based on the preceding findings and conclusions the following recommendations were forwarded:

1. From the finding it is concluded that, Most facilitators and WAEBTC haven't got on the job training in relation to their current position; there is a shortage of IFAE implementing guideline in the centers; sectors are not in a position to evaluate syllabus and curriculum of IFAE program; sectors have no common criteria to evaluate integrated functional adult education program; NGO and private sectors are not encouraged to invest their knowledge and economy on IFAE centers; adult education experts are not hired both in Woreda and adult education centers and both sector facilitators and Woreda AEBTC members have no clearly identified and known common schedules on IFAE program implementation. Therefore, it is recommended that, structure of adult education should be revised and rearranged so as to minimize the problem. Long and short term training should be designed so as to help and update facilitators and concerned experts knowledge.

2. Most sectors, Zone and Woreda cabinet, perceived adult Education program as difficult and additional tasks. Therefore awareness creation training and forum should be prepared for Zone and Woreda cabinets. Besides, program and its controlling mechanism should be designed for NGOs and private sectors to teach adult learners. ABE structure should be revised so as to make Health and agriculture sectors more participants.

3. Political leaders, elders, religion bodies' and all concerned communities should be awarded on the use of ABE program. on the other hands, training should be prepared on the way facilitators, technical committee and other concerned stakeholders' handle result documents and on duties and responsibilities of tasks and IFAE centers administrative structure.

4. Budget should be allocated so as to motivate members of the board and technical committee to come together and discuss on the agenda of adult education. Besides, guideline should be equally distributed all concerned sectors to work coordinately, lack of new graduated IFAE experts and qualified AEBTC members should be solved through treating adult education equally to formal education.

5. Follow-up and monitoring mechanisms should be designed, institutional and financial arrangements should 
be re modified so as to solve problems encountered concerned sectors coordination.

6. Border conflict, problem of policy and implementation strategies, problem of facilitators and teaching materials should be solved so as to minimize problem faced during $\mathrm{ABE}$ implementation

\section{References}

Abebe Anjulo Teklu Gebretsadik Mekonne Debara (22017)Enrollment and Participation of Adult Learners in Kindo Koysha Woreda of Wolaita Zone, Snnprs International Journal of African and Asian Studies www.iiste.org ISSN 2409-6938 An International Peer-reviewed Journal Vol.29,

Abebe Anjulo, Teklu Gebretsadik and Mekonne Debara (2017) Factors Affecting the Successful Enrollment and Participation of Adult Learners in Kindo Koysha Woreda of Wolaita Zone, Snnprs: International Journal of African and Asian Studies, 29, p, 6 ISSN 2409-6938 An International Peer-reviewed Journal

Abeje Gudeta (2017) A Study on Integrated Functional Adult Education Program in Pastoral Communities of Jarar Zone: Challenges and Opportunities: an international journal of innovative and Research Development. 6 , DOI No.: 10.24940/ijird/2017/v6/i7/MAY17077

Belay Tegene (2000), "Integrating Indigenous and Modern Agricultural Practices in the Drought Prone Areas of Ethiopia", in Zenebework Tadesse (ed.), Issues in Rural Development. Addis Ababa.

Coles, E.T. (1978). Adult Education in Developing Countries: Pergamon Press, Oxford. Proceedings of the Third Annual Research Conference of Jimma University

Dabali Hundessa, (2011). Factors Affecting the Participation of Women in Functional Adult Literacy Program In Menesibu and Nejo Woredas of West Wollega Zone of Oromia Region Unpublished MA Thesis: AAU

Dawson, C. (2002). Practical Research Methods: A User-Friendly Guide to Mastering Research techniques and Projects. Oxford: How to Books

Doronila, M.L.C (1996).Landscapes of Literacy: An Ethnographic Study of Functional Literacy in Marginal Philippine communities: London, Luzac Oriental

Fasokun, T.Katahoire, A. and Oduaran, A. (2005). The psychology of Adult Learning in Africa. CTP Book Printers, Cape Town.

Federal Democratic Republic of Ethiopia Population Census Commission Central Statistical Agency: The 2007 Population and Housing Census of Ethiopia Results for Country-Level Statistical Report ( August 2010) Brana Printing Enterprise: Addis Ababa

Federal Government of Ethiopia ( 2006); Plan for Accelerated and Sustained Development to End Poverty(PASDEP) (unpublished)

Fransman, J (2008)' Conceptualizing Literacy for Policy and Practice" Adult Education and Development no. 71. Holme, R. (2004); Literacy: An Introduction, Edinburgh: Edinburgh University Press.

IIZ/DVV Regional Office ( 2005). Poverty Reduction and Capacity building through Livelihood Skills Training: The EXPRO in Ethiopia( Special Edition) ( unpublished)

Indabawa, S.A. et.al (ed.)(2000). The State of Adult and Continuing Education in Africa. John Meinert Printing, Windhoek, Namibia.

Jimma University, January 26-27, 2012349

Lee, R. M., and Fielding, N. G. (2004). 'Tools for Qualitative Analysis' in Handbook of Data Analysis, London, Thousand Oaks, and New Delhi: Sage Publications.

Mbalisi, O. F (2015). Adult Education for Meaningful Socio-Economic Development in Nigeria. Journal of Social Science Studies. ISSN 2329-9150. Vol. 2, No. 2. doi:10.5296/jsss.v2i2.7799.

Ministry of Education (2005). Education Sector Development Plan III, BSPP. A.A

Ms. M. Mashinkila \& Mr. M. Assefaw. (2001) Appraisal Report Skills Development And Income Generation Project Republic Ofmalawi: Country Department South Region October African Development Fund Mlw/Pswi/2001/01 Language: English Original: English

Mulugeta Menkir(2002) The Implementation of Adult Literacy Program In East Gojjam Zone (Amhara Region) unpublished thesis Addis Ababa Ethiopia. Ila Panel policy On Adult And Lifelong Learning: International And National Perspectives

Nafukho, F., Amutabi, M. and Otunga, R.(2005). The Foundations of Adult Education in Africa. Pearson Education, Cape town

Oluoch,P.A.(2005). "Low Participation in Adult Literacy Classes: Reasons Behind It" Adult Education and Development No. 65

Pact Ethiopia,( 2008). the Status of Adult Functional Literacy project, A.A(unpublished).

Rogers, A. (1992). Adults Learning for Development. Cassell Educational Ltd. London

Samuel Asnake (2012) Linking Functional Adult Literacy (FAL) within Poverty Reduction Interventions: Potentials and Prospects in Ethiopia. Proceedings of the Third Annual Research Conference of Jimma University. January 26-27, P 330

Tebeje Molla, Revitalizing Adult Education In Ethiopia: The Importance Of Lifelong Learning Perspective 
Århus University, Denmark

Tilahun Workneh (1999). Adult Education in Ethiopia ( unpublished).

UNESCO (2006). Literacy Initiative for Empowerment: LIFE 2005-2015; Vision and Strategic 